\title{
Yliopistotyön huonontumisen
}

lyhyt historia

\section{Heikki Patomäki (2005). Yliopisto oyj. Tulosjohtamisen}

ongelmat - ja vaihtoehto. Gaudeamus.

Helsingin yliopiston kansainvälisen politiikan professori Heikki Patomäki herätti keväällä2005 runsaasti huomiota asettumalla julkisesti oman virkaasemansa likoon laittaen vastustamaan yliopistoihin sisään ajettavaa, tuloksellisuutteen perustuvaa palkkausjärjestelmää, UPJ:tä. Moinen suoraselkäisyys on hyvin kunnioitettavaa, mutta valitettavan harvinaista meikäläisissä yliopistopiireissä. Asian tiimoilta poiki järjestelmää vastustava valtakunnallinen protestiliike nettiadresseineen ja kriittisine keskusteluineen medioissa.

Kirja on keväisen UPJ-kuohunnan tulosta, mutta se kertoo paljosta muustakin. Se on kriittinen ja tärkeä puheenvuoro uusliberalistisen talous- ja yhteiskuntaideologian syöpymisestä politiikantekoon, hallintoon ja yleensä työelämään suomalaisen yliopistomaailman näkökulmasta.

Ansiokasta kirjassa on sen pyrkimys analysoida hallinnan muutoksia ja niiden perusteita ja seurauksia eri tasoilta. Luvussa 2 tarkastellaan UPJ:ntaustaideologioita sekä sen ensimmäisen vaiheen kokemuksia. Järjestelmä paikannetaan osaksi tulosohjauksen taustalla olevaa nk. uutta julkishallinto-oppia (New Public Management, NPM), joka vannoo markkinamekanismeihin. Siinä korostuu empiristinen ja atomistinen yksilö- ja yhteiskuntanäkemys.
Organisaatioiden ja yksilöiden kaikki toiminta ja tuotokset voidaan ja pitää objektiivisesti ja yksityiskohtaisesti arvioida, mitata ja tilittää ja siten tehokkaammin hallita ja ohjata. Tätähän UPJ juuri on: jokaisen yksittäisen yliopistotyöläisen tehtävät (nk. vaatiosa) ja niistä henkilökohtainen suoriutuminen (ns. henkiosa) arvioidaan ja raportoidaan moniportaisilla standardilomakkeilla. Palkkaus toimii sitten joko palkkiona tai rangaistuksena sen mukaan, kuinka lähiesimiehen "objektiivinen" arvio milloinkin osoittaa.

UPJ on siis tulosjohtamisen instrumentti.

Patomäki analysoi mielenkiintoisella tavalla järjestelmän perustuvan brittiläisen filosofi John Locken vuosisatoja sitten esittämälle "jokaiselle yksilölle kuuluu hänen oman työnsä tulokset" -oikeudenmukaisuusperiaatteelle, johon on sisäänrakennettu (sosiaalidarwinistinen) eriarvoisuuden, mm. palkkaerojen kasvattamisen oikeuttava logiikka. Sopii hyvin aikamme sikasuurten optioiden ja röyhkeään taloudellisen voitontavoittelun kulttuuriin.

\section{Odotettavissa olevia seuraumuksia}

Patomäki analysoi myös UPJ:n käytännön seuraamuksia. Käsittelyä elävöittää ja konkretisoi lainaukset käydystä verkkokes- kusteluista, joissa järjestelmä ei juurikaan saa yliopistoväen hyväksyntää. Kirjoittaja erittelee UPJ:n lukuisia vaikutuksia, joista osa on havaittavissa jo järjestelmän siirtymävaiheessa. Ensinnäkin koulutuksineen, arviointeineen ja neuvotteluineen systeemi on yksinkertaisesti lisännyt, erityisesti esimiesasemassa olevien oheistyötä, joka on tietysti pois varsinaisesta työstä, tutkimuksesta ja opetuksesta. Tätä on vielä korostanut se, että samalla rysäyksellä yliopistoissa siirryttiin uuteen tutkintojärjestelmään ja ryhdyttiin rakentamaan laadunvarmistusjärjestelmiä.

UPJ lisää palkkamenoja eli se tulee kalliiksi. Ja kun järjestelmän käskyttäjä eli valtiovalta ei peitä kaikkia lisäkuluja, yliopistot joutuvat säästämään palkkamenoistaan eli käytännössä vähentämään henkilökuntaa. Koko tulosohjausjärjestelmä tukee siis sopivasti meneillään olevaa korkeakouluverkoston rationalisointihankkeita osana valtionhallinnon tuottavuusohjelmaa.

Järjestelmään, jonka eräs verkkokeskustelija risti riidankylvöautomaatiksi, on myös sisäänrakennettu eriarvoisuuden siemenet, jotka uhkaavat työmotivaatiota. UPJ tulee entisestään vahvistamaan markkinalogiikkaa ja kilpailun eetosta yliopistojen käytännöissä, välineellistämään tutkimusta ja opetusta ja samalla ja rapauttamaan yhteisöllisyyttä On itsestään selvää, että järjestelmä lisää myös esimiesten virallista ja 
epävirallista valtaa korostaen valtahierarkioita, valvontaa ja kontrollia. Tämäkin sopii hyvin ajan pirtaan. Vahva johtajuushan on nyt yhtä kovassa huudossa kuin konsanaan 1930-luvulla. Patomäki näkeekin tulosohjausjärjestelmän jo nyt rapauttaneen sanan ja tutkimuksen vapautta ja yliopistodemokratiaa - sen mitä niistä enää on jäljellä.

Luvussa kolme kuvataan maan julkishallinnon muutoksia Suomessa 1980-luvun jälkipuoliskolta tähän päivään. Analyysissa käydään läpi keskus- ja aluehallinnon uudistukset, valtionyhtiöiden yksityistämiset ja valtionhallinnon palkkauudistus, jonka osa yliopistojen UPJjärjestelmäkin on. Lisäksi kuvataan saamaan aikaan toteutetut yliopistoa koskettavat hallinnolliset ja lainsäädännölliset uudistukset. Johtopäätöksenä esitetään, että nämä reformit on hallituskoalitioista riippumatta toteutettu hyvin johdonmukaisesti ja uusliberalistisen koulun eturivin hikipinko-oppilaan uutteruudella: uudistukset on ajettu ylhäältä käsin hätäisesti läpi, ilman turhia poliittisia keskusteluja, "pakkojen" sanelemina. Vastuu seurauksista on jätetty suorittavan tason inmisten niskoille.

\section{Kohti akateemista kapi- talismia}

Neljännessä luvussa Patomäki edelleen syventää tarkasteluaan tulosjohtamisen ja sen taustalla olevan uusklassisen talousteorian vaikutuksiin. Kirjoittajan analyysit ja pohdinnat ovat tuttuja lukuisista aiemmista korkeakoulututkimuksista, joissa yliopiston ja tieteenteon muutoksia on kuvattu sellaisilla kä- sitteillä kuin "akateeminen kapitalismi", "yritysyliopisto" tai korkeakoulutuksen "McDonaldisoituminen". Patomäen sanoma on koko lailla lohduton eikä valitettavasti aivan katteeton. Nykyisellä menolla yliopistosta on tulossa kovaa vauhtia tutkimuksen ja opetuksen halpatuotantolaitos, talouselämän ja hallintokoneiston vaateiden tahdoton puotipuksu. Hän osoittaa konkreettisin esimerkein sen, miten NPM:n soveltaminen tosiasiassa kääntyy omia tavoitteitaan vastaan. Kirjoittaja nostaa esiin myös hyvin tärkeän käsitteen, ideologian. Kun ideologia määritellään opeiksi ja ajatuksiksi, jotka ovat yhteiskunnan tiettyjen intressiryhmien etujen mukaisia, mutta jotka kyetään esittämään kaikkien yhteisinä etuina, tulee globaalin hallinnan tehokkuus talousdiskursseineen hyvin ymmärrettäväksi.

Kirjan viides luku on sivistysyliopiston, vapaan tieteen ja totuudentavoittelun sekä kriittisen järjen puolustuspuhe. $\mathrm{Pa}-$ tomäki ulottaa tarkastelunsa tietoteoreettisiin ja tieteenfilosofisiin sfääreihin, yliopistoinstituution historiaan myöden. Vauhtia haetan Habermasin tiedonintresseistä ja käsittely etenee oppikirjamaisesti Fullerin tieteen mallien erittelyn ja oikeudenmukaisuus-käsitteen (Rawls) syventävän analyysiin kautta tasa-arvoisen koulutuksen julistukseen. Luku on suhteellisen pitkä ja lukijalle jää vaikutelma, että uskottaviin johtopäätöksiin olisi päässyt kenties vähemmälläkin opetuksella.

\section{Patomäen vaihtoehto}

Viimeisessä luvussa Patomäki palaa käytännön tasolle ja esittää vaihtoehtonsa nykyiselle yliopistopolitiikalle. Ehdotukset eivät suinkaan ole radikaaleja, vaan pikemminkin maltillisia ja hyvin perusteltuja kompromisseja vanhan ja uuden välillä. Osa ehdotuksista merkitsisi paluuta vanhaan, kuten sisäänottokiintiöiden keskitetty suunnittelu, osa puolestaan siirtymiä uuteen kuten ajatus henkilön ylentämisestä virkakategoriassa hänen tieteellisen meritoitumisensa perusteella.

Kokonaisuudessaan Patomäen ehdotukset ovat yliopistotyöläisten näkökulmasta perusjärkeviä. Nykyisestä tulosohjausjärjestelmästä on luovuttava ja näin byrokratian ja muun oheistoiminnan vähenemisen seurauksena vapautuvat resurssit tulisi suunnata tutkimukseen ja opetukseen ja erityisesti perusrahoitukseen. Sanoma on, että nykyisellä politiikalla on todellisia vaihtoehtoja niin Suomessa kuin globaalisti. Kaikkea ei voi eikä saa alistaa kilpailulle ja mammonalle: "Yliopisto on osa ihmiskunnan oppimis-ja kehittymisprosessia." (s. 165).

\section{Tärkeä, mutta viimeis- telemätön}

Patomäen kirja on mielenkiintoinen lukukokemus. Teos on sukua Juha Siltalan Työelämän huononemisen lyhyelle historialle, joskin viimeksi mainittu painii huomattavasti raskaammassasarjassa. Patomäen kijalla on myös ongelmansa. Jäsentelyssä on toivomisen varaa, mikä kielii kirjan tekemisen lyhyestä aikataulusta. Se rönsyilee, paikoin on tarpeetonta toistoa. Kirjaan on mahdutettu niin oppikirjamaista teoreettista 
analyysia kaavioineen, tilastoineen ja käsitemäärittelyineen kuin yliopistoväen provokatiivisia emotionaalisia nettivuodatuksia. Ilmaisussaan Patomäki on kuitenkin selkeä ja viestin perille menoa helpottaa lukujen loppuun sommitellut johtopäätökset.

Kenen pitäisi kirjaan tutustua? Ainakin jokaisen itseään kunnioittavan yliopistolaisen. Erityisesti sen pitäisi lukea uuden toimintapolitiikan suunnittelusta ja toteuttamisesta vastuussa oleva hallintoeliitti, etunenässä poliitikot ja ne elinkeinoelämän elämän edustajat, jotka kiivaimmin ovat vaatineet sivistyksen hävittämistä yliopistoista. Valitettavasti taitaa olla niin, että näiden taholta teos vaietaan kuoliaaksi: "ldeologiaan kuuluu myös ristiriitojen ja konfliktien torjuminen sekäse, ettänykyisyys esitetään väistämättömänä ja luonnollisena"(s.108).
Valitettavasti kirjassa kuvattuja kehityssuuntia yliopistossa ei ole pysäyttäminen - olivatpa argumentit kuinka vakuuttavia tahansa. Kovin taitamattomasti, liian nopeasti ja arrogantisti

lanseeratun UPJ:n käyttöönottoa ei näytä yliopistoissa enää estävän mikään. Kaikessa ristiriitaisuudessaan ja byrokraattisessa yksioikoisuudessaan järjestelmä kohtelee yliopistolaisia kantilaisessa mielessä alaikäisinä. Järjestelmän sisäänajo on ollut tragikoomista. Esimerkiksi missään vaiheessa tämän hallinnollisen sekoilun keskellä - ei vielä tätä kirjoitettaessakaan loppuvuodesta 2005 millään osapuolella tunnu olevan tuon taivaallista tietoa siitä, miten uudistus tulee ihan oikeasti vaikuttamaan työntekijöiden palkkaukseen.

Rahallisia seurauksia pelottavimpia UPJ:n kaltaisille politiikan tekniikoille ovat kuiten- kin niiden ihmismieltä ja yhteisöllisyyttä korruptoivat vaikutukset. Instituutiot ja rakenteethan muovaat yksilöiden ajattelua; haluja toiveita pyrkimyksiä ja moraalia. Ihmisillä on taipumus, kuten Patomäki toteaa, puolustella ja järkeistää tekojaan, takertua sosiaalisen paineen alaisuudessa (ennen kaikkea oman edun ollessa kyseessä) virallisiin totuuksiin, silloinkin kun ne perustuvat virhepäätelmiin ja toiveajatteluun todellisuudesta.

Käytännön toiminnan tasolta katsottuna tulosjohtaminen ja sen viimeisin vaihe, UPJ on hahmottunut itselleni ennen kaikkea mielentilaksi. Siitä voivat innostua ainoastaan inmiset, joiden sisintä elähdyttävät johtamisen hurmio, normiriemu, raportointivimma, arviointiusko, laatufetisismi sekä tehokkuusfasismi.

ARTO JAUHIAINEN 